\title{
EDITORIAL
}

\section{ROLE OF A UNIVERSITY TEACHER IN THE PRESENT ERA}

\author{
A. Ghani Siddiqui
}

Universities are considered the highest seats of learning in any country. Hence, by default, university teachers are also placed at a higher pedestal than teachers of undergraduate colleges. Being knowledgeable, though a pre-requisite, is not the only virtue required of a university teacher. Above all, he should have the ability to lead since he is considered to be a leader of the learned community of the society at large. Acceptance of the teacher by the students is a trait whose importance cannot be undermined. Some are born teachers; put them in any situation and they will prove their worth as an educator. Others, however, are not as fortunate. They have to work hard to acquire this talent and work still harder to turn this talent into a skill. Modern era with teaching aids has made this endeavour easy for those who sincerely want to have them recognised as a capable teacher. Modern gadgets and innovations, unknown only a few decades back, have not only crept into but have also become an indispensible part of the educational system today. It is in the interest of the individual, aspiring to be a good teacher to keep himself abreast with the rapidly changing technology and employ it judiciously.

Rapid increasing migration of populations, increasing globalisation and ever more international training of physicians make it prudent that the medical teacher should avoid parochialism in medical education and medical practice. ${ }^{1}$ However, a good teacher would not depend on the vagaries of medical cases given in textbooks printed in western countries but make an outright effort to muster patients with regional diseases for teaching medicine. If collecting a big sample of patients appears too daunting, he should practice the technique of "simulation", so well known and well practiced in modern, high risk professions such as aviation and space exploration.

The role of a medical teacher is also changing. The present generation, whom he has to teach, is a lot more intelligent than its predecessors. Availability of vast knowledge on the net and accessibility to yet unpublished research work means that students expect their teachers to be well-versed in the current medical developments. There is also an increased awareness of student's rights and hence it is prudent to involve the students in the decision making in educational system. Their feedback in this regard is very valuable and must be given due weightage while devising the educational policy. The audit of the modern university teacher helps improve standards of education. Instructional strategy has to be based on this feedback rather than the whims and bookish attitude of the teacher. The modern teacher needs to revise his instructional methodology. The traditional lecture system, though not very efficient, will stay in our universities for an unforeseeable future. Lectures are tools for covering a large group of students and enables presentation of a large amount of information. It also allows the presence of a teacher (showmanship) enabling a feeling of security amongst the participants. ${ }^{2}$ Use of modern teaching aids can be used to make large group teaching an interesting experience for the young minds. Educational gadgets can also be used to get instant feedback from the students. The assessment of the teacher by the students during the lecture is a valuable tool to improve the teacher's performance. The Higher Education Commission (HEC) is striving hard in this direction and the university teachers should welcome such decisions instead of opposing them. Medical university enjoys a more prominent position in the community compared to other professional universities; hence the medical teacher also stands taller than other university teachers. He has to remember and follow the motto that "if you teach, you learn twice". Age should not be a bar to learning.

However, astounding our claims may be, it is a wellknown fact that our educational standards are declining and the community is aware of it. If not today, we may be answerable to the community tomorrow for this disaster. Of the three stake holders involved in the educational systems i.e. the students, the teacher and the government, students are the least to be blamed for this tragedy. Leaving aside a tiny minority, they are eager to learn and hence they should not be denied this right. The special status a university teacher enjoys in the society is due to these very students. It is therefore the prime duty of the teacher to play its due role in imparting quality education to the students. On its part, appointment of university faculty purely on merit is the minimum the government can do to stop the declining standards of medical education. Incompetent teachers, appointed or promoted on political grounds are like termites devouring the very fabric of the education structure. Such mediocre teachers and professors use unethical and immoral methods to keep their chair. This has led to corruption, which is more of moral corruption than a financial one. It's the professor that gives dignity to the chair and not vice versa. A chair that stands on four legs of dedication, knowledge, sincerity and hard work is the one that commands respect and dignity. A chair that rests on 
corruption, sycophancy, false grandeur and incompetence will not stand for long in the fast changing environment of today's world.

The medical teachers in general and the Professors in particular should make a sincere effort to set their departmental objectives to meet the needs of both the medical students and the patients. Satisfaction to both these stake holders would ultimately benefit the community at large. These objectives have to be tailored in such a way as to make them measurable and achievable. From time to time, these objectives should be assessed to see if they have been achieved or not. This means that those involved in teaching and training should ensure that what they are doing is effective, efficient and also makes a significant contribution to the health care of the target population in addition to fulfilling the needs of the students. ${ }^{3}$ If one feels that these objectives have been accomplished, they should be raised to the next achievable level. The goal must be to meet the learning needs of the students and the health requirements of the patients while keeping in pace with the current developments both in science and medicine.

Being a good teacher is not an easy task. Being knowledgeable is just one attribute. There is a long list of meaningful traits that need to be mastered and followed religiously to achieve this divine position. A University professor must:

- Be aware of health and educational needs of the community and has a genuine desire to provide them. He should act as a true leader and should make an earnest effort to find means to solve these problems.

- Actively design, implement and evaluate the departmental objectives he has set for himself and his team.

- $\quad$ Not only use existing clinical and scientific knowledge to teach but must aggressively indulge in research which is truly genuine and ethical.

- Educate the students and not lecture them.

- Set an example others can follow. He should be a man of integrity and impeccable character undeterred by difficulties and hurdles. He should make a conscious effort to develop all the characteris- tics and attitudes required of his post including dependability and a sense of responsibility.

- Motivates both his juniors and peers.

- Indulge in postgraduate teaching and training. This is highly rewarding and provides a sense of satisfaction and achievement.

- Regularly evaluate him and be open to improvement from whatever source it comes from, even from the students.

- Should be accessible to the students at all times, listen to their problems and should make a sincere endeavour to solve them.

- Inculcate ability to relate to, communicate with and show concern and respect for his students. He should consider his students as junior colleagues and should treat them as such.

Medical education is a continuing process which starts with pre-medical studies and continues through preclinical and clinical studies, internship and leads to vocational and specialized training for a particular career in medicine. ${ }^{4}$ It must be appreciated that the very nucleus of all medical activities is the teacher. The main ingredient of the medical education should be continuous assessment. This includes assessment of self, assessment of peers, assessment of students, assessment of aims and objectives and assessment of teaching strategy. Gone are the days when university teachers and professors enjoyed an unchallenged position. The changing tides of the global village the world has become and the sharp edge of competition we are exposed to means that we either shape up or ship out!

\section{REFERENCES}

1. A spectrum of clinical simulations in basic medicine. WHO workshop on patient management simulations; June 1976: P.7.

2. Guilbert JJ. WHO Educational Handbook. 1976: P. 221.

3. Katz FM. Guidelines for evaluating training programme for the health personnel. World Health Organization offset publication No. 38.1978; P.5.

4. Recommendations as to basic medical education. General Medical Council, UK. 1967; P. 4.

\begin{tabular}{l|}
\hline AUTHOR AFFILIATION: \\
Dr. A. Ghani Siddiqui \\
Professor of Surgery (Retired) \\
Liaquat University of Medical and Health Sciences \\
Jamshoro, Sindh - Pakistan.
\end{tabular}

